\title{
Effects of $660 \mathrm{~nm}$ low-level laser therapy on muscle healing process after cryolesion
}

\author{
Natalia C. Rodrigues, PhD; ${ }^{1}$ Lívia Assis, PhD $;^{2}$ Kelly R. Fernandes, MSc; ${ }^{2}$ Angela Magri; ${ }^{2}$ Daniel A. Ribeiro, \\ PhD; ${ }^{2}$ Roberta Brunelli, MSc; ${ }^{3}$ Daniela C. C. Abreu, PhD; ${ }^{4}$ Ana Claudia M. Renno, hbD $^{2 *}$ \\ ${ }^{1}$ Department of Physiotherapy, Federal University of São Carlos, São Carlos, São Paulo, Brazil; ${ }^{2}$ Department of Bio- \\ sciences, Federal University of São Paulo, Santos, São Paulo, Brazil; ${ }^{3}$ Department of Surgery, Faculty of Medical Sci- \\ ences, State University of Campinas, Campinas, São Paulo, Brazil; ${ }^{4}$ Biomechanics, Medicine and Rehabilitation of \\ Locomotor System Department, University of São Paulo, Ribeirão Preto, São Paulo, Brazil
}

\begin{abstract}
The aim of this study was to evaluate the effects of $660 \mathrm{~nm}$ low-level laser therapy (LLLT) on muscle regeneration after cryolesion in rat tibialis anterior muscle. Sixty-three Wistar rats were divided into a control group, $10 \mathrm{~J} / \mathrm{cm}^{2}$ lasertreated group, and $50 \mathrm{~J} / \mathrm{cm}^{2}$ laser-treated group. Each group formed three subgroups ( $n=7$ per group), and the animals were sacrificed 7, 14, or $21 \mathrm{~d}$ after lesion. Histopathological findings revealed a lower inflammatory process in the lasertreated groups after $7 \mathrm{~d}$. After $14 \mathrm{~d}$, irradiated animals at both fluences showed higher granulation tissue, new muscle fibers, and organized muscle structure. After $21 \mathrm{~d}$, full tissue repair was observed in all groups. Moreover, irradiated animals at both fluences showed smaller necrosis area in the first experimental period evaluated. MyoD immunoexpression was observed in both treated groups $7 \mathrm{~d}$ postinjury. Myogenin immunoexpression was detected after 7 and $14 \mathrm{~d}$. The higher fluence increased the number of blood vessels after 14 and $21 \mathrm{~d}$. These results suggest that LLLT, at both fluences, positively affects injured skeletal muscle in rats, accelerating the muscle-regeneration process.
\end{abstract}

Key words: animal model, cryolesion, gene expression, histopathological analysis, laser therapy, muscle regeneration, muscle tissue, MyoD, myogenin, rehabilitation.

\section{INTRODUCTION}

Skeletal muscle injuries are extremely common in rehabilitation centers. They can occur through a variety of mechanisms, ranging from direct mechanical deformation (such as muscle laceration, strain, and contusion) to indirect damage related to ischemia and neurologic dysfunction [1-2]. Although muscle tissue can regenerate after injury, the process tends to be slow, often resulting in functional and structural muscle atrophy, contracture, pain, and reinjury [3-4].

Muscle regeneration is a highly orchestrated process that ideally leads to complete functional recovery. This process is characterized by inflammatory response, activation of muscle satellite cells, and formation of new myofibers [5]. The temporal and spatial interaction of the

\footnotetext{
Abbreviations: $\mathrm{CG}=$ control group, $\mathrm{G} 10=10 \mathrm{~J} / \mathrm{cm}^{2}$ lasertreated group, $\mathrm{G} 50=50 \mathrm{~J} / \mathrm{cm}^{2}$ laser-treated group, $\mathrm{IgG}=$ immunoglobulin G, LLLT = low-level laser therapy, MRF = myogenic regulatory factor, $\mathrm{PBS}=$ phosphate buffered saline, $\mathrm{TA}=$ tibialis anterior, $\mathrm{US}=$ ultrasound.

*Address all correspondence to Ana Claudia M. Renno, PhD; Department of Bioscience, Federal University of São Paulo (UNIFESP), Av. Ana Costa, 95, Vila Mathias, Santos, São Paulo, 11050-240, Brazil. Email: a.renno@unifesp.br http://dx.doi.org/10.1682/JRRD.2012.08.0147
} 
different kinds of cells is regulated by a series of cellsignaling molecules and growth factors, which induce maturation of muscle cells to create a competent muscle structure at the injury site [6].

The family of myogenic regulatory factors (MRFs), such as myoD and myogenin, have an important role in this event. MyoD is markedly more effective in activation and differentiation of satellite cells, while myogenin is an important factor for terminal differentiation and fusion myoblasts in mature muscle fiber, restoring normal muscle architecture [7]. Furthermore, the formation of new vessels is necessary to ensure adequate blood supply during the healing process. This event is regulated by the vascular endothelial growth factor that exerts multiple effects on the vascular endothelium, including stimulation of endothelial cell proliferation, rapid induction of microvascular permeability, promotion of endothelial cell survival, stimulation of endothelial cell adhesion and migration, and subsequent connection between new vessels and the preexisting circulation [8].

Despite the excellent capacity of muscle tissue to regenerate after injury, in critical situations such as extensive myofibrilar degeneration or poorly vascularized injuries, the process of muscle healing can be delayed [89]. In this context, there is a need to develop treatments able to accelerate muscle cell proliferation and prevent fibrosis during the healing process, which would decrease the rehabilitation time and regenerative processes, producing a return to the previous level of function as quickly and thoroughly as possible [9-10].

In this context, low-level laser therapy (LLLT) seems to be an efficient resource for skeletal muscle recovery, and its effectiveness has been demonstrated over the years [11-12]. Several studies have shown that laser irradiation favors the regeneration of skeletal muscle in animal and human models, increasing the number of muscle fibers, mitochondrial density, angiogenesis, and myotube formation, thereby shortening the inflammatory phase and accelerating the proliferative and maturation phases of skeletal muscle regeneration [13-14].

Despite the stimulatory effects of laser on tissue repair, investigators have applied it at a wide variety of doses, which makes it difficult to compare published results and determine the best laser parameters for evoking the best tissue response [15-18]. Therefore, it is important to examine the effects of different fluences of LLLT to define its safety and efficiency.
These encouraging effects of LLLT on muscle metabolism formed the basis for the current in vivo study, which aimed to evaluate the biological response to laser irradiation in a model of cryolesion in rats. Cryolesion is an injury model well recognized to induce necrosis in a delimited area of skeletal muscle and regeneration [1921]. This lesion produces myonecrosis, tissue disruption, edema, hypercontracted fibers, and inflammatory cell infiltration (especially neutrophils and macrophages) [22]. These characteristics are similar to those found after high-intensity eccentric exercise, which is also a valid method used to induce muscle damage, leading to muscle fiber disruption, infiltration by inflammatory cells, and swelling [23-24].

We hypothesized that laser irradiation could modulate the inflammatory infiltrate and increase neoangiogenesis, stimulating the expression of the myogenic immunoexpression responsible for the regeneration process of skeletal muscle. In this context, the present study aimed to examine the influence of LLLT, comparing two different fluences (10 and $\left.50 \mathrm{~J} / \mathrm{cm}^{2}\right) 7,14$, and $21 \mathrm{~d}$ after cryolesion on the tibialis anterior (TA) through morphology and muscle tissue structure analysis. Inflammatory process, granulation tissue, tissue structure, number of blood vessels, and presence of immunomarkers were evaluated histologically and by immunohistochemistry analysis.

\section{METHODS}

\section{Experimental Groups}

Sixty-three Wistar male rats (weighing $300 \pm 20 \mathrm{~g}$ ) were used and maintained under a controlled temperature $\left(22^{\circ} \mathrm{C} \pm 2{ }^{\circ} \mathrm{C}\right)$ and light-dark periods of $12 \mathrm{~h}$ and with free access to water and a commercial diet.

All animals were divided into a control group (CG) with injured animals and no treatment, injured animals treated with $10 \mathrm{~J} / \mathrm{cm}^{2}(\mathrm{G} 10)$, and injured animals treated with $50 \mathrm{~J} / \mathrm{cm}^{2}$ (G50). Each group then formed three different subgroups ( $n=7$ per group) of animals sacrificed 7, 14, or $21 \mathrm{~d}$ after injury. Treatments started $48 \mathrm{~h}$ after surgery and were performed every $24 \mathrm{~h}$ for 5,10 , and 15 sessions.

\section{Experimental Design}

\section{Surgery}

Surgical procedures (cryolesion) were performed based on those described by Miyabara et al. [20], under 
anesthesia with $40 \mathrm{mg} / \mathrm{kg}$ ketamine (Dopalen, Vetbrands; São Paulo, Brazil) and $20 \mathrm{mg} / \mathrm{kg}$ xylazine (Anasedan, Vetbrands). After anesthesia, the skin around the right TA muscle was shaved and cleaned. Then, a transversal cut (about $1 \mathrm{~cm}$ ) of the skin over the middle of the muscle was carried out, exposing the muscle. A flat top end $(0.5 \times$ $0.5 \mathrm{~cm}$ ) of rectangular iron bar, precooled in liquid nitrogen, was then kept for $10 \mathrm{~s}$ on the center of the muscle. The procedure was repeated twice consecutively, with a time interval of $30 \mathrm{~s}$. Finally, the skin was sutured, and thereafter, animals were kept for several hours on a warm plate $\left(37^{\circ} \mathrm{C}\right)$ to prevent hypothermia.

\section{Low-Level Laser Therapy Protocol}

A $660 \mathrm{~nm}$ laser (Ga-Al-As) (MM Optics, São Carlos Equipment; São Paulo, Brazil) was used in this study. The following parameters were used: continuous wavelength, $4.0 \mathrm{~mm}^{2}$ beam diameter, with $10 \mathrm{~J} / \mathrm{cm}^{2}(20 \mathrm{~mW}$, $20 \mathrm{~s}, 0.4 \mathrm{~J}$ total energy per point) and $50 \mathrm{~J} / \mathrm{cm}^{2}(40 \mathrm{~mW}$, $50 \mathrm{~s}, 2 \mathrm{~J}$ energy per point). Irradiation was performed through the punctual contact technique on one point above the area of the injury. The treatments started $48 \mathrm{~h}$ postsurgery and were performed 5 times/wk (each $24 \mathrm{~h}$ ), followed by an interval of $48 \mathrm{~h}$. Rats were sacrificed by $\mathrm{CO}_{2}$ suffocation on days 7,14 , and 21 postinjury.

\section{Histopathological Analysis}

Muscles were submitted to a standard protocol. Muscle samples were fixed in 10 percent buffered formalin (Merck; Darmstadt, Germany) and embedded in paraffin. Longitudinal axis sections $(5 \mu \mathrm{m})$ were cut using a microtome (Leica Microsystems SP 1600; Nussloch, Germany). Five sections of each sample were stained with hematoxylin and eosin (HE stain, Merck) and analyzed. Histopathological evaluation was performed through a light microscope (Olympus, Optical Co Ltd; Tokyo, Japan) with $40 \times$ magnification by a pathologist who was blinded to the treatment. Inflammatory process, granulation tissue, necrosis area, focal or diffuse myofibrillary degeneration, and tissue structure were considered [10].

\section{Morphometry of Injured Area}

For morphometric evaluation, one histological crosssection of each TA muscle located in the central region of muscle injury was chosen to measure the cross-sectional area of both injured and uninjured muscle, using software for morphometry (Axiovision 3.0.6 SP4, Carl Zeiss; Jena, Germany). Images were used to reconstruct the total muscle cross-sectional area, allowing the identifica- tion and measurement of both injured and uninjured areas. A double-blind procedure was used for both muscle cross-section image selection and injured and uninjured muscle area measurements.

\section{Number of Blood Vessels}

For determination of the number of blood vessels at the injured area, five fields from different regions following the injured area were obtained by light microscope (Olympus, Optical Co Ltd) at a magnification of $40 \times$. The number of blood vessels was counted in each field by morphometric software (Axiovision 3.0.6 SP4). This was performed in five histological sections for each animal, and then the mean number of blood vessels per animal and per group was calculated [25].

\section{Immunohistochemistry}

Serial longitudinal muscle sections of $4 \mu \mathrm{m}$ were deparaffinated in xylene, rehydrated in graded ethanol, and then pretreated by microwave (Brastemp; São Paulo, Brazil) with $10 \mathrm{mM}$ citric acid buffer $(\mathrm{pH}=6)$ for 3 cycles of $5 \mathrm{~min}$ each at $850 \mathrm{~W}$ for antigen retrieval. The material was preincubated with 0.3 percent hydrogen peroxide in phosphate buffered saline (PBS) for $5 \mathrm{~min}$ for inactivation of endogenous peroxidase and then blocked with 5 percent normal goat serum in PBS solution for $10 \mathrm{~min}$. The specimens were then incubated with antiMyoD and antimyogenin antibodies (Santa Cruz Biotechnology, Inc; Dallas, Texas) at a concentration of 1:400. Incubation was carried out overnight at $4{ }^{\circ} \mathrm{C}$ within the refrigerator and followed by two washes in PBS for 10 $\mathrm{min}$. The sections were then incubated with biotin-conjugated secondary antibody (anti-rabbit immunoglobulin G [IgG]) (Vector Laboratories; Burlingame, California) at a concentration of 1:200 in PBS for $1 \mathrm{~h}$. The sections were washed twice with PBS before the application of preformed avidin biotin complex conjugated to peroxidase (Vector Laboratories) for $45 \mathrm{~min}$. The bound complexes were visualized by the application of a 0.05 percent solution of 3-3'-diaminobenzidine and counterstained with Harris hematoxylin. For control studies of antibodies, the serial sections were treated with rabbit IgG (Vector Laboratories) at a concentration of 1:200 in place of the primary antibody. Additionally, internal positive controls were performed with each staining bath.

Immunohistochemical data were evaluated by an experienced pathologist (DAR) under subjective morphologic analysis as established in previous studies conducted by our group [10]. 


\section{Statistical Analysis}

The results are given as means and standard deviations. Data for the morphometry of the injured area and number of blood vessels analysis were evaluated by twoway analysis of variance, followed by the post hoc Student-Newman-Keuls method. Level of statistical significance was defined as $p<0.05$. Statistical evaluation was carried out using STATISTICA 7 (StatSoft, Inc; Tulsa, Oklahoma).

\section{RESULTS}

\section{Histopathological Analysis}

In the CG, there was an intense inflammatory reaction $7 \mathrm{~d}$ postinjury composed mainly of mononuclear inflammatory cells (Figure 1(a)). After $14 \mathrm{~d}$ postinjury, the histological analysis revealed the presence of granulation tissue and newly formed muscle fibers (Figure 1(b)). After $21 \mathrm{~d}$, full tissue repair was observed (Figure 1(c)).

In the experimental groups exposed to LLLT, some remarkable differences were detected at both fluences $\left(10 \mathrm{~J} / \mathrm{cm}^{2}\right.$ and $\left.50 \mathrm{~J} / \mathrm{cm}^{2}\right)$ when compared with the CG. However, no histological differences were found between the two fluences. After $7 \mathrm{~d}$, inflammatory infiltrate was observed but less intense than in the CG (Figure 1(d) and 1(g)). In addition, granulation tissue and some newly muscle fibers were noticed in this period (Figure 1(d) and $\mathbf{1 ( g ) )}$. Following $14 \mathrm{~d}$ postinjury, muscle tissue presented a higher amount of granulation tissue, newly formed muscle fibers, and an organized muscle structure at the area of injury (Figure 1(e) and 1(h)). At $21 \mathrm{~d}$ postinjury, full tissue repair was noticed in both groups (Figure 1(f) and 1(i)).

\section{Immunohistochemistry}

\section{Myogenin Expression}

Immunohistochemical data for myogenin and MyoD are summarized in Figures 2 and 3, respectively. Immunostaining for both markers was detected in the nucleus of muscle cells and circumjacent areas.

In the $\mathrm{CG}$, no immunoexpression of myogenin was detected in any experimental period, indicating a negative expression for this group (Figures 2(a)-(c)). Nevertheless, in the group exposed to LLLT at $10 \mathrm{~J} / \mathrm{cm}^{2}$, a positive myogenin immunoexpression was noticed 7 and $14 \mathrm{~d}$ postinjury (Figure 2(d) and 2(e), respectively). Fol- lowing $21 \mathrm{~d}$, a negative immunoexpression was detected (Figure 2(f)). Regarding animals treated at $50 \mathrm{~J} / \mathrm{cm}^{2}$, the same picture was observed; i.e., myogenin was detected 7 and $14 \mathrm{~d}$ postinjury (Figures $\mathbf{2 ( g )}$ and 2(h), respectively). Negative immunoexpression was observed in the last period evaluated (Figure 2(i)).

\section{MyoD Expression}

In the $\mathrm{CG}$, myoD immunoexpression was not detected in any experimental analyzed in this study $(7,14$, and $21 \mathrm{~d}$ postinjury) (Figure 3(a)-3(c)), indicating negative immunostaining in this group for all periods evaluated in this setting. Nevertheless, a positive myoD immunoexpression was noticed in the group exposed to LLLT at $10 \mathrm{~J} / \mathrm{cm}^{2}$ only at $14 \mathrm{~d}$ postinjury (Figure 3(e)). A negative immunoexpression was observed 7 and $21 \mathrm{~d}$ postsurgery in this fluence (Figure 3(d) and 3(f), respectively). Regarding laser therapy at $50 \mathrm{~J} / \mathrm{cm}^{2}$, the same picture was observed; i.e., myogenin was detected $14 \mathrm{~d}$ postinjury (Figure 3(h)) and negative immunoexpression was observed at 7 and $21 \mathrm{~d}$ (Figure 3(g) and 3(i), respectively).

\section{Morphometry of Injured Area}

Figure 4 shows the morphometry of the injured area in the three experimental periods. At the first experimental period, the $660 \mathrm{~nm}$ laser at both fluences produced a significant decrease in the injury area compared with the CG (CG vs G10: $p<0.001$; CG vs G50: $p<0.001$ ). Similar injury area results were found for all the groups in the other two experimental periods.

\section{Number of Blood Vessels}

Seven days postsurgery no statistical difference was found between the CG and treated groups. At the second experimental period, a statistically higher number of blood vessels was found in G50 $(p<0.02)$ than in CG and G10. Similarly, $21 \mathrm{~d}$ after surgery, the number of blood vessels was also significantly increased in G50 $(p<0.03)$ compared with CG and G10 (Figure 5).

\section{DISCUSSION}

The present study evaluated the in vivo response of the application of LLLT in a rat TA cryolesion model. We hypothesized that laser therapy would enhance muscle metabolism, accelerating the process of healing. The main findings demonstrated that the irradiated groups, at both 

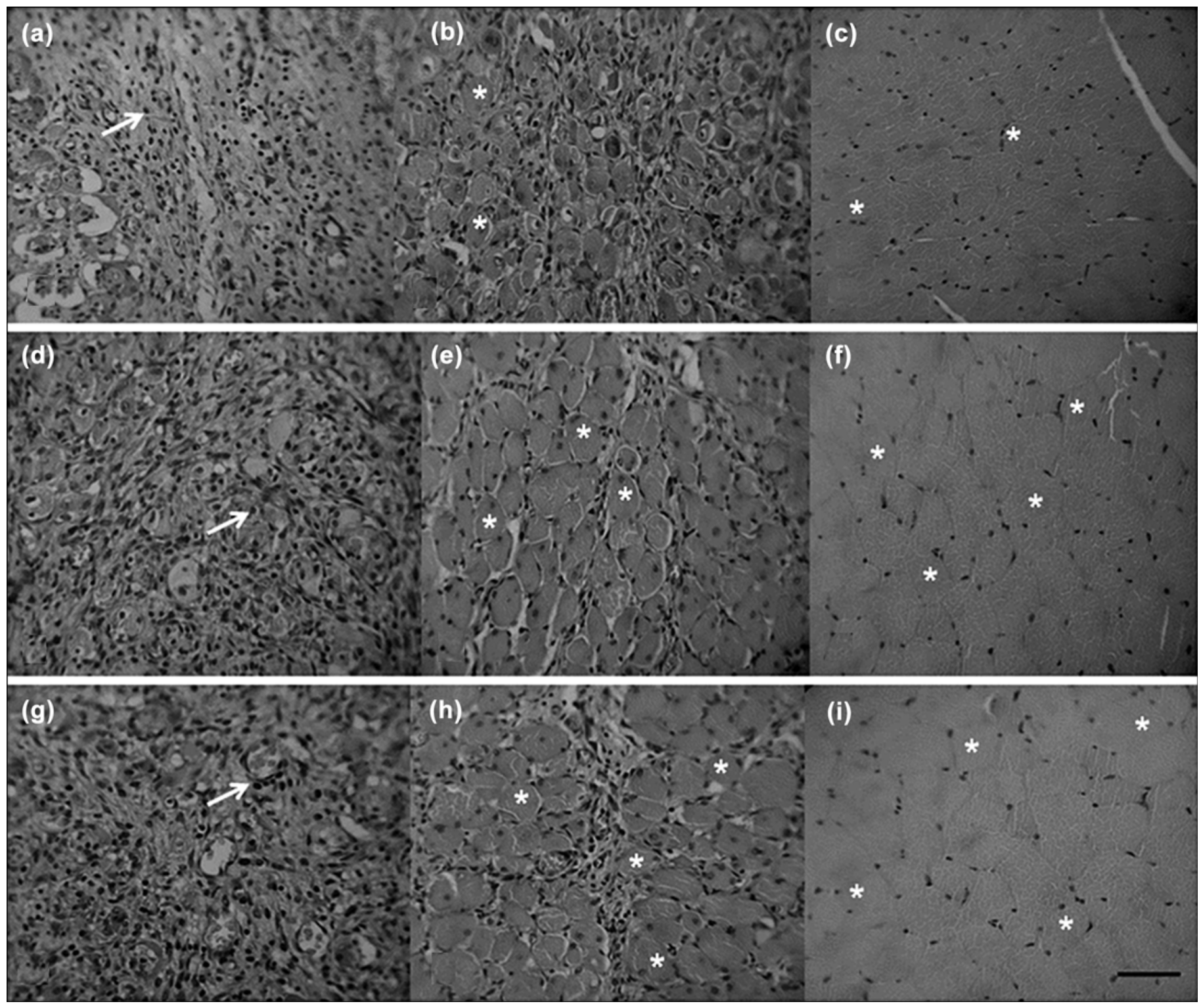

\section{Figure 1.}

Histological sections of injured muscle. (a)-(c) Control group 7, 14, and $21 \mathrm{~d}$ after surgery, respectively. (d)-(f) $10 \mathrm{~J} / \mathrm{cm}^{2}$ lasertreated animals 7, 14, and $21 \mathrm{~d}$ after surgery, respectively. (g)-(i) $50 \mathrm{~J} / \mathrm{cm}^{2}$ laser-treated animals 7,14 and $21 \mathrm{~d}$ after surgery, respectively. Asterisks indicate inflammatory infiltrate and granulation tissue. Arrows indicate new muscle fiber. Hematoxylin and eosin stain. $10 \times$.

fluences, presented a better histological pattern, with earlier recruitment of cell infiltrate, higher amount of newly formed muscle fiber, and a more organized muscle tissue structure at the lesion. Furthermore, our results demonstrated a smaller necrosis area in the laser-treated groups $7 \mathrm{~d}$ postsurgery. The immunohistochemical analysis revealed an upregulated expression of myogenin in both irradiated groups at 7 and $14 \mathrm{~d}$ and an upregulated expression of myoD at $14 \mathrm{~d}$. In addition, LLLT at $50 \mathrm{~J} / \mathrm{cm}^{2}$ produced a significant increase in the number of blood vessels at the site of the injury.

Laser phototherapy is based on the photobiostimulation of cells and tissues [11]. Furthermore, many studies have investigated the effects of LLLT in a series of different 


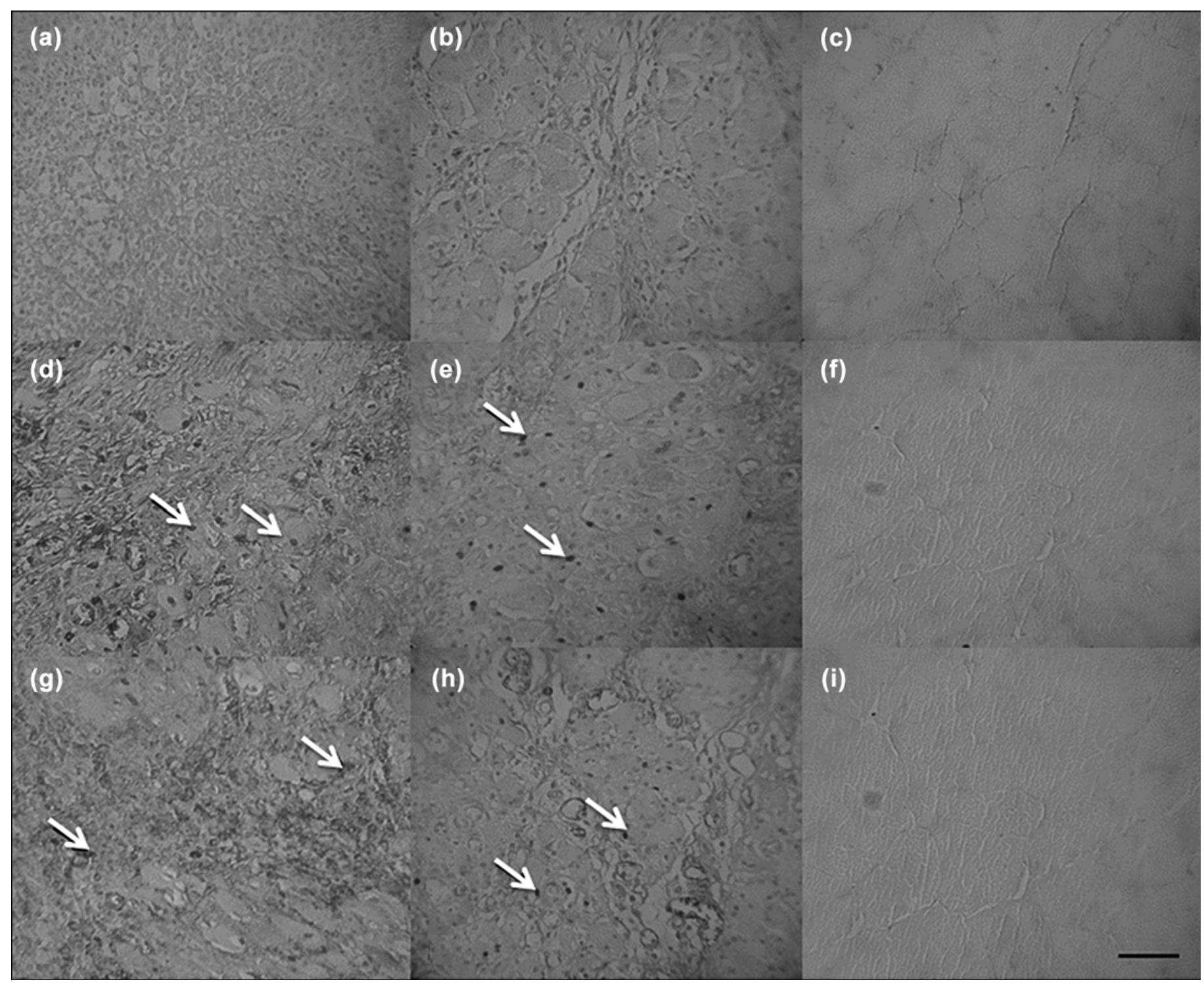

\section{Figure 2.}

Immunohistochemical staining for myogenin. (a)-(c) Control group 7, 14, and $21 \mathrm{~d}$ after surgery, respectively. (d)-(f) $10 \mathrm{~J} / \mathrm{cm}^{2}$ lasertreated animals 7, 14, and $21 \mathrm{~d}$ after surgery, respectively. (g)-(i) $50 \mathrm{~J} / \mathrm{cm}^{2}$ laser-treated animals 7,14 and $21 \mathrm{~d}$ after surgery, respectively. Arrows indicate myogenin immunoexpression. 10×.

pathological conditions to stimulate tissue repair [26-28]. Pires et al. showed that laser therapy $\left(780 \mathrm{~nm} ; 7.7 \mathrm{~J} / \mathrm{cm}^{2}\right.$; $75 \mathrm{~s}$ ) reduced interleukin $6, \mathrm{COX}-2$, and transforming growth factor beta in an experimental model of tendinitis in rats [26]. Demidova-Rice et al. demonstrated that a single laser exposure stimulated the healing of wounds in mice [27]. In addition, Pallotta et al. demonstrated that LLLT $(810 \mathrm{~nm})$ reduced the inflammatory process in an experimental model of knee osteoarthritis in rats [28].
The histological and morphometric analysis showed that laser therapy attenuated the pathological features induced by cryolesion. Such findings may reflect the positive effects of laser irradiation on muscle regeneration, evidencing its myogenic potential and capacity to activate satellite and myogenic cells, culminating in better muscle fiber organization at the site of the injury. This is in agreement with Melo et al. [29], who affirmed that laser therapy decreased the number of inflammatory cells and increased 


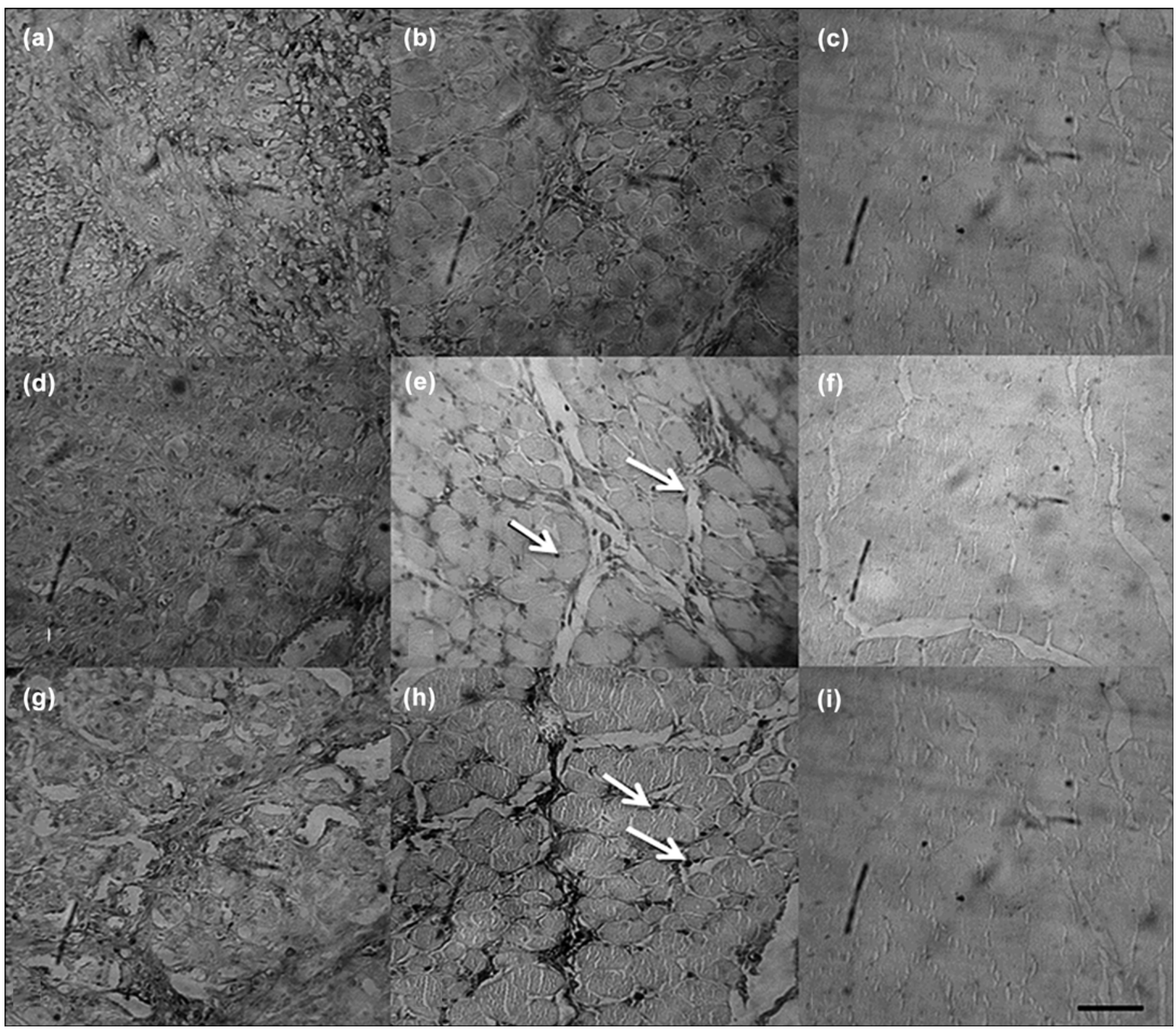

Figure 3.

Immunohistochemical staining of MyoD. (a)-(c) Control group 7, 14, and $21 \mathrm{~d}$ after surgery, respectively. (d)-(f) $10 \mathrm{~J} / \mathrm{cm}^{2}$ lasertreated animals 7, 14, and $21 \mathrm{~d}$ after surgery, respectively. (g)-(i) $50 \mathrm{~J} / \mathrm{cm}^{2}$ laser-treated animals 7,14 and $21 \mathrm{~d}$ after surgery, respectively. Arrows indicate MyoD immunoexpression. 10×.

the amount of elastic fibers in the wound-healing process, which could explain the positive effect of laser on accelerating tissue repair. Also, our group, comparing the effects of $830 \mathrm{~nm}$ laser therapy and low-intensity pulsed ultrasound (US) on muscle healing, observed that the laser-irradiated animals presented minor degenerative changes of muscle tissue when compared with control and US-treated animals
[10]. The same results were found by Demir et al. [30], who observed that laser irradiation (904 nm; $1 \mathrm{~J} / \mathrm{cm}^{2} ; 6 \mathrm{~mW}$ ) was more effective than US in accelerating wound healing.

In addition, immunohistochemistry analysis showed that laser therapy, at both fluences, produced an upregulation of myogenin and MyoD expression during the process of muscle healing. Interestingly, this analysis 


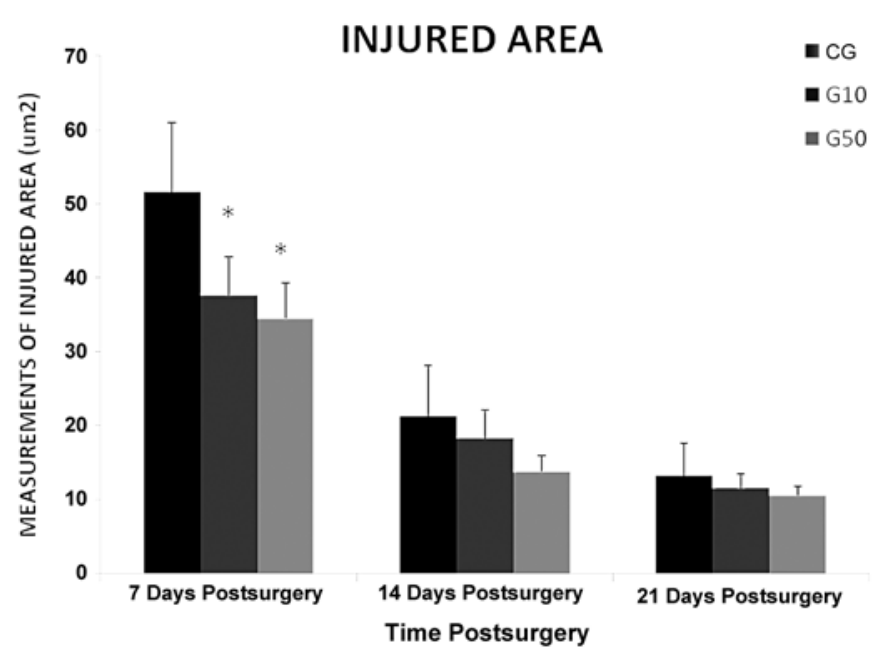

Figure 4.

Mean and standard deviation of injury area. CG = control group, $\mathrm{G} 10=10 \mathrm{~J} / \mathrm{cm}^{2}$ laser-treated animals, $\mathrm{G} 50=50 \mathrm{~J} / \mathrm{cm}^{2}$ lasertreated animals.

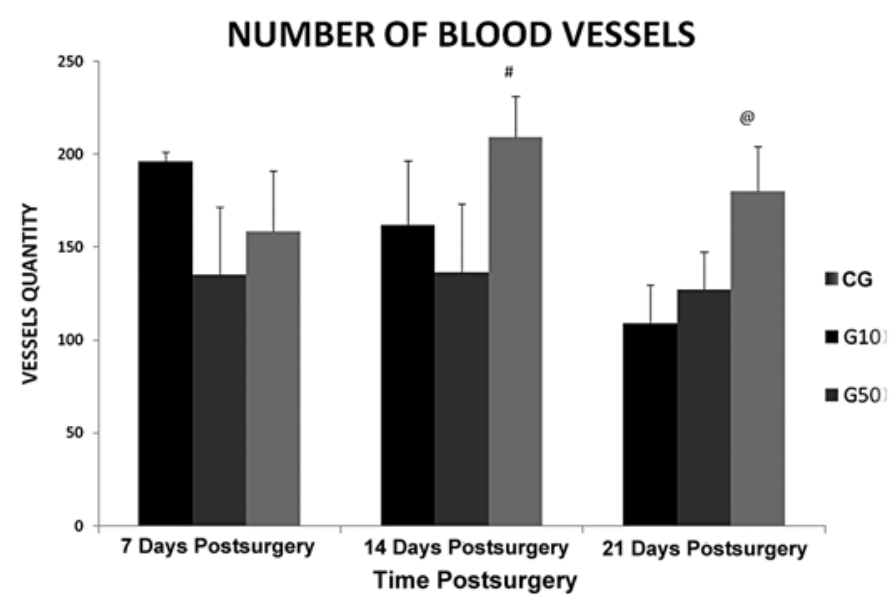

Figure 5.

Mean and standard deviation of number of blood vessels. CG = control group, G10 = $10 \mathrm{~J} / \mathrm{cm}^{2}$ laser-treated animals, G50 = 50 J/ $\mathrm{cm}^{2}$ laser-treated animals.

demonstrated a negative expression in the CG. MyoD and myogenin play a key role during neonatal myogenesis and have a regulatory function in the processes of muscle plasticity, adaptation, and regeneration in adult muscle [31-33]. Both myogenin and MyoD are responsible for satellite cell differentiation [34]. The arrival of satellite cells is crucial during muscle regeneration, because these cells can transform into myoblasts to substitute for the damaged muscle fibers [33-34]. When LLLT is applied to tissue, the light is absorbed and can modulate cell biochemical reactions, increasing the synthesis of DNA, RNA, and cell-cycle regulatory proteins [35-36]. Therefore, the cited effects of LLLT may have induced increased myogenin and myoD gene expression, which culminated in upregulated expression of both MRFs. Therefore, the better organization of the muscle fibers and minor levels of inflammatory cells during the first periods after irradiation may be related to the higher levels of MyoD and myogenin expression.

Furthermore, the present study demonstrated a stimulatory effect of LLLT, mainly at the higher fluence, on blood vessel growth. An adequate blood perfusion is essential to guarantee injured tissue regeneration and, consequently, the success of the repair procedure [37]. Vascular photomodulation can be associated with the reduction of inflammatory cells and stimulation of macrophages, Tlymphocytes, endothelial cells, and fibroblast migration during the healing process, resulting in accelerated tissue healing [38]. Gonçalves et al. showed that the GaAsAl laser applied with an energy density of $60 \mathrm{~J} / \mathrm{cm}^{2}$ was more effective in stimulating neoangiogenesis than $30 \mathrm{~J} / \mathrm{cm}^{2}$ [37]. Furthermore, Corazza et al. reported that a dose of $20 \mathrm{~J} / \mathrm{cm}^{2}$ effectively increased fibroblast proliferation and neoangiogenesis in skin wounds [39].

The parameters of LLLT for optimal stimulation still need to be determined, and the molecular details involved in tissue repair have to be investigated [10]. These affirmations highlight the importance of studies exploring the effects of different parameters. Interestingly, in the present study similar beneficial effects were observed at both dosages.

\section{CONCLUSIONS}

This study demonstrates that the LLLT had positive effects on injured skeletal muscle in rats, accelerating the muscle regeneration process by increasing the number of blood vessels and upregulation of myogenin and MyoD immunoexpression, which may have resulted in better tissue organization at the site of the injury. Although further clinical studies using functional tests are required, the findings of this work point to a promising utilization of such therapeutic modalities for tissue repair. 


\section{ACKNOWLEDGMENTS}

Concept and design: N. C. Rodrigues, R. Brunelli, D. C. Abreu, A. C. Renno.

Acquisition of data: N. C. Rodrigues, R. Brunelli.

Analysis and interpretation of data: N. C. Rodrigues, R. Brunelli,

K. R. Fernandes, A. Magri, L. Assis, D. A. Ribeiro, D. C. Abreu,

A. C. Renno.

Drafting of manuscript: N. C. Rodrigues.

Critical revision of manuscript for important intellectual content:

N. C. Rodrigues, R. Brunelli, L. Assis, D. A. Ribeiro, D. C. Abreu,

A. C. Renno.

Statistical analysis: N. C. Rodrigues, A. C. Renno.

Study supervision: A. C. Renno.

Financial Disclosures: The authors have declared that no competing interests exist.

Funding/Support: This material was based on work supported by Coordenação de Aperfeiçoamento de Pessoal de Nível Superior (CAPES Foundation/20226300).

Institutional Review: This study was conducted according to the Guiding Principles for the Care and Use of Laboratory Animals and was approved by the Committee of the Federal University of São Carlos.

\section{REFERENCES}

1. Li Y, Cummins J, Huard J. Muscle injury and repair. Curr Opin Orthop. 2001;12:409-15.

http://dx.doi.org/10.1097/00001433-200110000-00008

2. Baoge L, Van Den Steen E, Rimbaut S, Philips N, Witrvrouw E, Almqvist KF, Vanderstraeten G, Vanden Bossche LC. Treatment of skeletal muscle injury: a review. ISRN Orthop. 2012.

3. Menetrey J, Kasemkijwattana C, Day CS, Bosch P, Vogt M, $\mathrm{Fu}$ FH, Moreland MS, Huard J. Growth factors improve muscle healing in vivo. J Bone Joint Surg Br. 2000;82(1): 131-37. [PMID:10697329] http://dx.doi.org/10.1302/0301-620X.82B1.8954

4. Huard J, Li Y, Fu FH. Muscle injuries and repair: current trends in research. J Bone Joint Surg Am. 2002;84A(5):822-32. [PMID:12004029]

5. Tidball JG. Inflammatory processes in muscle injury and repair. Am J Physiol Regul Integr Comp Physiol. 2005; 288(2);R345-53. [PMID:15637171] http://dx.doi.org/10.1152/ajpregu.00454.2004

6. Järvinen TA, Järvinen TL, Kääriäinen M, Aärimaa V, Vaittinen S, Kalimo H, Järvinen M. Muscle injuries: optimising recovery. Best Pract Res Clin Rheumatol. 2007;21(2):317-31. [PMID:17512485] http://dx.doi.org/10.1016/j.berh.2006.12.004

7. Bryan BA, Walshe TE, Mitchell DC, Havumaki JS, SaintGeniez M, Maharaj AS, Maldonado AE, D’Amore PA. Coordinated vascular endothelial growth factor expression and signaling during skeletal myogenic differentiation. Mol
Biol Cell. 2008;19(3):994-1006. [PMID:18094043]

http://dx.doi.org/10.1091/mbc.E07-09-0856

8. Piedade MC, Galhardo MS, Battlehner CN, Ferreira MA, Caldini EG, de Toledo OM. Effect of ultrasound therapy on the repair of gastrocnemius muscle injury in rats. Ultrasonics. 2008;48(5):403-11. [PMID:18384832]

http://dx.doi.org/10.1016/j.ultras.2008.01.009

9. Markert CD, Merrick MA, Kirby TE, Devor ST. Nonthermal ultrasound and exercise in skeletal muscle regeneration. Arch Phys Med Rehabil. 2005;86(7):1304-10.

[PMID:16003655]

http://dx.doi.org/10.1016/j.apmr.2004.12.037

10. Rennó AC, Toma RL, Feitosa SM, Fernandes K, Bossini PS, de Oliveira P, Parizotto N, Ribeiro DA. Comparative effects of low-intensity pulsed ultrasound and low-level laser therapy on injured skeletal muscle. Photomed Laser Surg. 2011;29(1):5-10. [PMID:21166589]

http://dx.doi.org/10.1089/pho.2009.2715

11. Mesquita-Ferrari RA, Martins MD, Silva JA Jr, da Silva TD, Piovesan RF, Pavesi VC, Bussadori SK, Fernandes KP. Effects of low-level laser therapy on expression of TNF- $\alpha$ and TGF- $\beta$ in skeletal muscle during the repair process. Lasers Med Sci. 2011;26(3):335-40. [PMID:21053039] http://dx.doi.org/10.1007/s10103-010-0850-5

12. de Souza TO, Mesquita DA, Ferrari RA, Dos Santos Pinto D Jr, Correa L, Bussadori SK, Fernandes KP, Martins MD. Phototherapy with low-level laser affects the remodeling of types I and III collagen in skeletal muscle repair. Lasers Med Sci. 2011;26(6):803-14. [PMID:21761120]

http://dx.doi.org/10.1007/s10103-011-0951-9

13. Cressoni MD, Dib Giusti HH, Casarotto RA, Anaruma CA. The effects of a 785-nm AlGaInP laser on the regeneration of rat anterior tibialis muscle after surgically-induced injury. Photomed Laser Surg. 2008;26:461-66.

[PMID:18800950] http://dx.doi.org/10.1089/pho.2007.2150

14. Amaral AC, Parizotto NA, Salvini TF. Dose-dependency of low-energy $\mathrm{HeNe}$ laser effect in regeneration of skeletal muscle in mice. Lasers Med Sci. 2001;16(1):44-51.

[PMID:11486338]

http://dx.doi.org/10.1007/PL00011336

15. Abe M, Fujisawa K, Suzuki H, Sugimoto T, Kanno T. Role of $830 \mathrm{~nm}$ low reactive level laser on the growth of an implanted glioma in mice. Keio J Med. 1993;42(4):177-79. [PMID:8126974]

16. Khadra M, Lyngstadaas SP, Haanaes HR, Mustafa K. Determining optimal dose of laser therapy for attachment and proliferation of human oral fibroblasts cultured on titanium implant material. J Biomed Mater Res A. 2005; 73A(1):55-62. [PMID:15704112] http://dx.doi.org/10.1002/jbm.a.30270 
17. Albertini R, Aimbire F, Villaverde AB, Silva JA Jr, Costa MS. COX-2 mRNA expression decreases in the subplantar muscle of rat paw subjected to carrageenan-induced inflammation after low level laser therapy. Inflamm Res. 2007;56(6):228-29. [PMID:17607546] http://dx.doi.org/10.1007/s00011-007-6211-6

18. Prabhu V, Rao SB, Chandra S, Kumar P, Rao L, Guddattu V, Satyamoorthy K, Mahato KK. Spectroscopic and histological evaluation of wound healing progression following Low Level Laser Therapy (LLLT). J Biophotonics. 2012; 5(2):168-84. [PMID:22174176] http://dx.doi.org/10.1002/jbio.201100089

19. Bibikova A, Oron U. Promotion of muscle regeneration in the toad (Bufo viridis) gastrocnemius muscle by lowenergy laser irradiation. Anat Rec. 1993;235(3):374-80.

[PMID:8430907]

http://dx.doi.org/10.1002/ar.1092350306

20. Miyabara EH, Martin JL, Griffin TM, Moriscot AS, Mestril R. Overexpression of inducible $70-\mathrm{kDa}$ heat shock protein in mouse attenuates skeletal muscle damage induced by cryolesioning. Am J Physiol Cell Physiol. 2006;290(4): C1128-38. [PMID:16291818] http://dx.doi.org/10.1152/ajpcell.00399.2005

21. Baptista RR, Scheeren EM, Macintosh BR, Vaz MA. Lowfrequency fatigue at maximal and submaximal muscle contractions. Braz J Med Biol Res. 2009;42(4):380-85.

[PMID:19330267] http://dx.doi.org/10.1590/S0100-879X2009000400011

22. Assis L, Moretti AI, Abrahão TB, de Souza HP, Hamblin MR, Parizotto NA. Low-level laser therapy (808 nm) contributes to muscle regeneration and prevents fibrosis in rat tibialis anterior muscle after cryolesion. Lasers Med Sci. 2013;28(3):947-55. [PMID:22898787]

http://dx.doi.org/10.1002/1sm.22077

23. Miles MP, Andring JM, Pearson SD, Gordon LK, Kasper C, Depner CM, Kidd JR. Diurnal variation, response to eccentric exercise, and association of inflammatory mediators with muscle damage variables. J Appl Physiol. 2008; 104(2):451-58. [PMID:18079262] http://dx.doi.org/10.1152/japplphysiol.00572.2007

24. Sakamoto A, Maruyama T, Naito H, Sinclair PJ. Acute effects of high-intensity dumbbell exercise after isokinetic eccentric damage: interaction between altered pain perception and fatigue on static and dynamic muscle performance. J Strength Cond Res. 2010;24(8):2042-49.

[PMID:20634739] http://dx.doi.org/10.1519/JSC.0b013e3181d8e881

25. Vatansever F, Rodrigues NC, Assis LL, Peviani SS, Durigan JL, Moreira FM, Hamblin MR, Parizotto NA. Low intensity laser therapy accelerates muscle regeneration in aged rats. Photonics Lasers Med. 2012;1(4):287-97.

\section{[PMID:23750328]}

http://dx.doi.org/10.1515/plm-2012-0035

26. Pires D, Xavier M, Araújo T, Silva JA Jr, Aimbire F, Albertini R. Low-level laser therapy (LLLT; $780 \mathrm{~nm}$ ) acts differently on mRNA expression of anti- and pro-inflammatory mediators in an experimental model of collagenase-induced tendinitis in rat. Lasers Med Sci. 2011;26(1):85-94.

[PMID:20737183]

http://dx.doi.org/10.1007/s10103-010-0811-z

27. Demidova-Rice TN, Salomatina EV, Yaroslavsky AN, Herman IM, Hamblin MR. Low-level light stimulates excisional wound healing in mice. Lasers Surg Med. 2007; 39(9):706-15. [PMID:17960752]

http://dx.doi.org/10.1002/1sm.20549

28. Pallotta RC, Bjordal JM, Frigo L, Leal Junior EC, Teixeira S, Marcos RL, Ramos L, Messias FM, Lopes-Martins RA. Infrared (810-nm) low-level laser therapy on rat experimental knee inflammation. Lasers Med Sci. 2012;27(1): 71-78. [PMID:21484455]

http://dx.doi.org/10.1007/s10103-011-0906-1

29. Melo VA, Anjos DC, Albuquerque Júnior R, Melo DB, Carvalho FU. Effect of low level laser on sutured wound healing in rats. Acta Cir Bras. 2011;26(2):129-34.

[PMID:21445476]

http://dx.doi.org/10.1590/S0102-86502011000200010

30. Demir H, Menku P, Kirnap M, Calis M, Ikizceli I. Comparison of the effects of laser, ultrasound, and combined laser + ultrasound treatments in experimental tendon healing. Lasers Surg Med. 2004;35(1):84-89.

[PMID:15278933]

http://dx.doi.org/10.1002/lsm.20046

31. Dedkov EI, Kostrominova TY, Borisov AB, Carlson BM. MyoD and myogenin protein expression in skeletal muscles of senile rats. Cell Tissue Res. 2003;311(3):401-16. [PMID:12658448]

32. Warren GL, Summan M, Gao X, Chapman R, Hulderman T, Simeonova PP. Mechanisms of skeletal muscle injury and repair revealed by gene expression studies in mouse models. J Physiol. 2007;582(Pt 2):825-41.

[PMID:17478534]

http://dx.doi.org/10.1113/jphysiol.2007.132373

33. Friedrichs M, Wirsdöerfer F, Flohé SB, Schneider S, Wuelling M, Vortkamp A. BMP signaling balances proliferation and differentiation of muscle satellite cell descendants. BMC Cell Biol. 2011;12:26. [PMID:21645366] http://dx.doi.org/10.1186/1471-2121-12-26

34. Marsh DR, Criswell DS, Carson JA, Booth FW. Myogenic regulatory factors during regeneration of skeletal muscle in young, adult, and old rats. J Appl Physiol. 1997;83(4): 1270-75. [PMID:9338436]

35. Stein A, Benayahu D, Maltz L, Oron U. Low-level laser irradiation promotes proliferation and differentiation of 
human osteoblasts in vitro. Photomed Laser Surg. 2005; 23(2):161-66. [PMID:15910179]

http://dx.doi.org/10.1089/pho.2005.23.161

36. Karu, TI, Lubart R. Effects of low-power light on biological systems V. Proceedings of SPIE; 2000 Dec 9; Amsterdam (the Netherlands).

37. Gonçalves RV, Novaes RD, Cupertino Mdo C, Moraes B, Leite JP, Peluzio Mdo C, Pinto MV, da Matta SL. Timedependent effects of low-level laser therapy on the morphology and oxidative response in the skin wound healing in rats. Lasers Med Sci. 2013;28(2):383-90. [PMID:22354548]

38. Gonçalves RV, Novaes RD, Matta SL, Benevides GP, Faria FR, Pinto MV. Comparative study of the effects of galliumaluminum-arsenide laser photobiomodulation and healing oil on skin wounds in wistar rats: a histomorphometric study. Photomed Laser Surg. 2010;28(5):597-602. [PMID:20961227] http://dx.doi.org/10.1089/pho.2009.2669

39. Corazza AV, Jorge J, Kurachi C, Bagnato VS. Photobiomodulation on the angiogenesis of skin wounds in rats using different light sources. Photomed Laser Surg. 2007; 25(2):102-6. [PMID:17508845]

http://dx.doi.org/10.1089/pho.2006.2011

Submitted for publication August 23, 2012. Accepted in revised form January 8, 2013.

This article and any supplementary material should be cited as follows:

Rodrigues NC, Assis L, Fernandes KR, Magri A, Ribeiro DA, Brunelli R, Abreu DC, Renno AC. Effects of 660 $\mathrm{nm}$ low-level laser therapy on muscle healing process after cryolesion. J Rehabil Res Dev. 2013;50(7):985-96. http://dx.doi.org/10.1682/JRRD.2012.08.0147

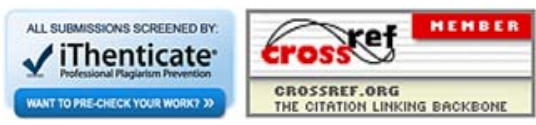


